\title{
Comparative Life-Cycle Analysis of Insulation Materials in a Dwelling, Addressing Alternative Heating Systems and Life Spans
}

\author{
Seyedeh Shiva Saadatian, Fausto Freire, and Nuno Simões
}

\begin{abstract}
Insulation materials can play a significant role not only in supporting essential savings in operating costs but also in decreasing the environmental load of the building stock. This paper presents an integrated energy, cost and environmental life-cycle analysis for three types of insulation material [polyurethane (PUR), extruded polystyrene (XPS) and expanded polystyrene (EPS)] applied to a Portuguese reference building for single-family houses. The insulation materials were considered in external thermal insulation composite systems (ETICs). The seasonal calculation method was implemented to calculate operational energy. Life-cycle costing was employed following the net present value method. Alternative heating systems (heat pumps vs electric heaters) were assessed and a sensitivity analysis was performed to analyze the influence of the discount rate (5 and $7 \%$ ) and building lifespan (30 or 50 years). The results of comparative assessment showed that the net present value gained by EPS along 50 years lifespan of the building was $16 \%$ more than XPS with the lowest value, and the required energy as well as global warming impact caused by XPS was approximately $9 \%$ more than PUR with the lowest value. The results also indicated that changing the heating system from electric heater to heat pump, decreased energy required for space heating by $10 \%$, and increasing the discount rate from 5 to $7 \%$ caused the reduction of total net savings from $31 \%$ (EPS) to $41 \%$ (PUR). In addition, reduction of the building lifespan from 50 to 30 years decreased total net savings from $23 \%$ (EPS) to $28 \%$ (XPS). The results provide useful insight for building design decisions, energy management policies, etc., supporting the identification and prioritization of those parameters, in order to improve building performance.
\end{abstract}

Index Terms - Life-cycle assessment, life-cycle cost analysis, sensitivity analysis, thermal insulation material.

\section{INTRODUCTION}

Building sector accounts for more than $40 \%$ of global energy use and $\mathrm{CO}_{2}$ emissions in International Energy Agency (IEA) member countries [1]. Thermal insulation of building envelope is regarded as an effective factor to reduce energy demand in buildings [2]-[14]. This research study includes the comparative assessment of external thermal insulation composite system (ETICS) with three alternative insulation

Manuscript received March 20, 2015; revised September 17, 2015.

Seyedeh Shiva Saadatian is with the Department of Mechanical Engineering, University of Coimbra, Portugal (e-mail: shivasaadatian@student.dem.uc.pt).

Fausto Freire is with the ADAI-LAETA, Department of Mechanical Engineering, University of Coimbra, Portugal (e-mail: fausto.freire@dem.uc.pt).

Nuno Simões is with the CICC - Construction Sciences Research Unit, Civil Engineering Department of University of Coimbra, Portugal (e-mail: nasimoes@itecons.uc.pt). materials applied to a reference building for new single-family houses in Portugal. This study has chosen three common types of insulation materials, namely Expanded polystyrene (EPS), Extruded polystyrene (XPS) and Polyurethane (PUR) which are more used in Portuguese buildings. In this paper, the life-cycle processes by the insulation materials including production, transport and operation phase have been characterized in terms of energy and environmental impacts. The required energy for other operation phase activities such as lighting, cooking, domestic hot water and electric appliances has been excluded since it is not affected by the wall solutions.

\section{Methodology}

\section{A. Life-Cycle Assessment}

Life-cycle assessment (LCA) is a methodology to evaluate the potential impacts throughout the product's life. The general framework of LCA consists of four interrelated phases: goal and scope definition; life-cycle inventory (LCI); life-cycle impact assessment (LCIA) and interpretation [9], [15]-[23]. A life-cycle model was developed for a reference building for new single family houses (with a living area of $165 \mathrm{~m}^{2}$ and wall area of $163.13 \mathrm{~m}^{2}$ ) located in Bragança, Portugal. The functional unit nominated for this study was 1 square meter of living area over a period of 50 years (building lifespan). This paper aims to conduct a comparative assessment of ETICS with three alternative insulation materials in terms of energy, cost and environmental performances during use-phase following a base scenario according to the declared functional unit. This study has chosen three common types of insulation materials, namely Expanded polystyrene (EPS), Extruded polystyrene (XPS) and Polyurethane (PUR) which are more used in Portuguese buildings. The other additional goal is assessment of alternative heating systems (heat pumps vs electric heaters) and implementing a sensitivity analysis to analyze the influence of discount rate ( 5 and $7 \%$ ) and the building lifespan (30 or 50 years). Table I presents inventory data relating with alternative insulation materials and thicknesses applied in ETICS. CML 2000 LCIA method was applied in order to evaluate an environmental impact of global warming (GW).

TABLE I: BUILDING MATERIALS INVENTORY (BASE SCENARIO)

\begin{tabular}{ccc}
\hline \hline Insulation materials & Thickness $(\mathrm{mm})$ & Mass per functional unit $(\mathrm{kg})$ \\
\hline XPS & 40 & 1.20 \\
EPS & 40 & 1.00 \\
PUR & 40 & 1.40 \\
\hline \hline
\end{tabular}




\section{B. Energy Performance Assessment}

Energy assessment throughout the life-cycle perspective provides the improvement of building performance and energy efficiency in building [16], [24], [25]. There were several parameters influenced on the LCA of residential buildings: the climate related to the temperatures and the buildings insulation thicknesses, the use of different materials, the energy sources and the heating/cooling system. Many studies have mentioned the importance of each stage of a building life-cycle [26]-[28]. Some studies have emphasized on the wide share of energy consumption by operation phase of buildings [25], [29], [30].

Energy consumption is increasing in order to the increase of population and development of living quality. Building sector is one of the contributors having a considerable potential of reducing the energy consumption. One approach to save the building energy is applying thermal insulation materials contributing to the reduction the heat transfer [12], [31].

The energy performance of the building when changing type and thickness of insulation materials was calculated with seasonal calculation method (based on ISO 13790) [32].

\section{Life-Cycle Cost Analysis}

A life-cycle cost analysis provides a comprehensive relationship between initial investment for insulation materials and benefits of heating and cooling costs reduction in the use-phase. In this study, a life-cycle cost analysis was implemented by net present value method. Net present value (NPV) of each insulation material was calculated by Equation (1). Discount rate was considered $5 \%$ for the base scenario.

$$
N P V(i, N)=\sum_{t=0}^{N} \frac{R t}{(1+i)^{t}}
$$

where, $t$ represents the time of the cash flow (Building lifespan), $i$ represents the discount rate, $R_{t}$ represents the net cash flow (cash inflow - cash outflow).

\section{RESULTS}

\section{A. Comparative Assessment Related With the Base Scenario}

The energy, cost and environmental assessment of three alternative insulation materials according to the base scenario is presented in Table II. Lifespan of the building was considered 50 years for the base scenario. In addition, electric heaters were assumed as heating system with efficiency value of 1 for the base scenario and discount rate was considered $5 \%$.

TABLE II: ENERGY, COST AND ENVIRONMENTAL ASSESSMENT (BASE SCENARIO)

\begin{tabular}{cccc}
\hline \hline $\begin{array}{c}\text { Insulation } \\
\text { materials }\end{array}$ & $\begin{array}{c}\text { Required energy } \\
\left(\mathrm{KWh} / \mathrm{m}^{2}\right)\end{array}$ & $\begin{array}{c}\mathrm{NPV} \\
(€)\end{array}$ & $\begin{array}{c}\mathrm{GW} \\
\left(\mathrm{kg} \mathrm{CO}_{2} \text { eq. }\right)\end{array}$ \\
\hline XPS $(40 \mathrm{~mm})$ & 2534 & 6275.09 & 190658.2 \\
EPS $(40 \mathrm{~mm})$ & 2492 & 7483.89 & 187498.1 \\
PUR $(40 \mathrm{~mm})$ & 2307 & 7477.70 & 173578.7 \\
\hline \hline
\end{tabular}

The results show that the net present value gained by EPS along 50 years lifespan of the building is $16 \%$ more than XPS with the lowest value. On the other hand, the required energy as well as global warming impact resulted by XPS is approximately $9 \%$ more than PUR, which is the lowest.

\section{B. Alternative Heating Systems (Heat Pumps Vs Electric Heaters)}

In this paper, an alternative heating system has been considered with different value for the efficiency. In based scenario, heating system was assumed electric heaters with efficiency value of 1 , whereas in this scenario heat pump was considered as an alternative system with efficiency value of 3.2. It should be mentioned that other parameters such as lifespan and discount rate were considered as the same as base scenario. Table III presents the energy, cost and environmental assessment of alternative insulation materials based on the new alternative heating system.

TABLE III: ENERGY, COST AND ENVIRONMENTAL ASSESSMENT (BASED ON THE NEW ALTERNATIVE HEATING SYSTEM)

\begin{tabular}{cccc}
\hline \hline $\begin{array}{c}\text { Alternative insulation } \\
\text { materials }\end{array}$ & $\begin{array}{c}\text { Required energy } \\
\left(\mathrm{KWh} / \mathrm{m}^{2}\right)\end{array}$ & $\begin{array}{c}\mathrm{NPV} \\
(€)\end{array}$ & $\begin{array}{c}\mathrm{GW} \\
(\mathrm{kg} \mathrm{CO} \\
\text { eq. })\end{array}$ \\
\hline XPS $(40 \mathrm{~mm})$ & 2289 & 6275.09 & 172224.4 \\
EPS $(40 \mathrm{~mm})$ & 2247 & 7483.89 & 169064.3 \\
PUR $(40 \mathrm{~mm})$ & 2062 & 7477.70 & 155144.9 \\
\hline \hline
\end{tabular}

Changing the heating system from electric heaters to heat pump resulted the reduction of required energy for space heating, as well as reduction of global warming impact by $10 \%$.

\section{A Sensitivity Analysis - Alternative Building Lifespans}

In this paper, the building lifespan was considered 50 years for the base scenario. In this subsection, a sensitivity analysis was performed to analyze the influence of building lifespan on required energy for space heating, global warming and net savings. An alternative building lifespan of 30 years has been assumed. It should be mentioned that other parameters such as heating system and discount rate were considered as the same as base scenario. Table IV presents the energy, cost and environmental assessment of alternative insulation materials based on the building lifespan of 30years.

TABLE IV: ENERGY, COST AND ENVIRONMENTAL ASSESSMENT (BASED ON THE BUILDING LIFESPAN OF 30 YEARS)

\begin{tabular}{cccc}
\hline \hline $\begin{array}{c}\text { Alternative insulation } \\
\text { materials }\end{array}$ & $\begin{array}{c}\text { Required } \\
\text { energy } \\
\left(\mathrm{KWh} / \mathrm{m}^{2}\right)\end{array}$ & $\begin{array}{c}\text { NPV } \\
(€)\end{array}$ & $\begin{array}{c}\mathrm{GW} \\
(\mathrm{kg} \mathrm{CO} \text { eq. })\end{array}$ \\
\hline XPS $(40 \mathrm{~mm})$ & 1373.4 & 4641.99 & 103334.6 \\
EPS $(40 \mathrm{~mm})$ & 1348.2 & 5789.73 & 101438.6 \\
PUR $(40 \mathrm{~mm})$ & 1237.2 & 5513.97 & 93086.9 \\
\hline \hline
\end{tabular}

By considering different lifespans for the reference building, it concludes that increasing the lifespan of the building has an influence on the net present values gained by the insulation materials.

The results show that the reduction of building lifespan from 50 years to 30 years caused the reduction of required 
energy and global warming by $46 \%$ and total net present value by $26 \%$ for XPS and PUR and $23 \%$ for EPS.

\section{A Sensitivity Analysis - Alternative Discount Rates}

As aforementioned, discount rate was considered $5 \%$ for the base scenario. A sensitivity analysis was performed to analyze the influence of discount rate on total net savings. An alternative discount rate of $7 \%$ has been assumed. It should be mentioned that other parameters such as lifespan and heating system were considered as the same as base scenario. Table V presents the net present values of alternative insulation materials based on the discount rate of $7 \%$. By increasing the discount rate, no changing was occurred relating with the required energy and global warming for the alternative insulation materials.

TABLE V: Net PRESENT VALUes (BASEd ON Discount Rate of 7\%)

\begin{tabular}{|c|c|}
\hline Alternative insulation materials & $\begin{array}{c}\text { NPV } \\
(€) \\
\end{array}$ \\
\hline XPS $(40 \mathrm{~mm})$ & 3751.84 \\
\hline EPS (40 mm) & 4866.29 \\
\hline PUR (40 mm) & 4443.60 \\
\hline
\end{tabular}

The results show that the increase of discount rate from $5 \%$ to $7 \%$ caused the reduction of net present values by $40 \%$ for XPS, $35 \%$ for EPS and $41 \%$ for PUR.

\section{CONCLUSION}

Buildings are responsible about $40 \%$ of primary energy consumption and therefore $\mathrm{CO}_{2}$ emissions [33]. Thermal insulation of building envelope is considered as an effective factor to reduce energy demand in buildings [2]-[4], [6], [8], [34], [35]. This study has chosen three common types of insulation materials, namely Expanded polystyrene (EPS), Extruded polystyrene (XPS) and Polyurethane (PUR) which are more used in Portuguese buildings. This paper aims to conduct a comparative assessment of ETICS with three alternative insulation materials during the operation phase when applied to the reference building for new single-family houses in Portugal. In addition, it aims to assess alternative heating systems (heat pumps vs electric heaters) and perform a sensitivity analysis to analyze the influence of discount rate (5 and 7\%) and the building lifespan (30 or 50 years).

By considering different lifespans for the reference building, it concludes that increasing the lifespan of the building has an influence on the net present values gained by the insulation materials. The results show that the net present value gained by EPS along 50 years lifespan of the building is $16 \%$ more than XPS with the lowest value.

On the other hand, the required energy as well as global warming impact resulted by XPS is approximately $9 \%$ more than PUR, which is the lowest. In addition, changing the heating system from electric heater to heat pump caused the reduction of required energy for space heating, as well as reduction of global warming impact by $10 \%$. The reduction of building lifespan from 50 years to 30 years resulted the reduction of required energy and global warming by $46 \%$ and total net present value by $26 \%$ for XPS and PUR and $23 \%$ for EPS. Subsequently, the increase of discount rate from $5 \%$ to
$7 \%$ caused the reduction of net present values by $40 \%$ for XPS, $35 \%$ for EPS and $41 \%$ for PUR.

Regarding the life-cycle cost of materials, net present value method was conducted for each insulation material. Results showed that the gained benefit of applying insulation materials during the building lifespan was much higher that the initial investment including the material cost and its installation labor fees. It was concluded that in terms of lifecycle cost, applying EPS and PUR gain more benefit in comparison with XPS. On the other side, less benefit is achieved after applying XPS in order to more initial investment for XPS.

\section{ACKNOWLEDGMENT}

This work has been framed under the Initiative Energy for Sustainability of the University of Coimbra and supported by the Energy and Mobility for Sustainable Regions - EMSURE

Project (CENTRO-07-0224-FEDER-002004) and Fundação para a Ciência e a Tecnologia (FCT) under project grant PTDC/SEN-TRA/117251/2010.

\section{REFERENCES}

[1] European Commission, "Energy efficiency and its contribution to energy security and the 2030 Framework for climate and energy policy," 2014.

[2] D. M. S. Al-Homoud, "Performance characteristics and practical applications of common building thermal insulation materials," Build. Environ., vol. 40, no. 3, pp. 353-366, Mar. 2005.

[3] M. H. Mazor, J. D. Mutton, D. A. M. Russell, and G. A. Keoleian, "Life cycle greenhouse gas emissions reduction from rigid thermal insulation use in buildings," J. Ind. Ecol., vol. 15, no. 2, pp. 284-299, Apr. 2011.

[4] N. Pargana, M. D. Pinheiro, J. D. Silvestre, and J. de Brito, "Comparative environmental life cycle assessment of thermal insulation materials of buildings," Energy Build., vol. 82, pp. 466-481, Jul. 2014.

[5] D. Anastaselos, E. Giama, and A. M. Papadopoulos, "An assessment tool for the energy, economic and environmental evaluation of thermal insulation solutions," Energy Build., vol. 41, no. 11, pp. 1165-1171, Nov. 2009.

[6] D. Anastaselos, S. Oxizidis, and A. M. Papadopoulos, "Energy, environmental and economic optimization of thermal insulation solutions by means of an integrated decision support system," Energy Build., vol. 43, no. 2-3, pp. 686-694, Feb. 2011.

[7] I. Axaopoulos, P. Axaopoulos, and J. Gelegenis, "Optimum insulation thickness for external walls on different orientations considering the speed and direction of the wind," Appl. Energy, vol. 117, pp. 167-175, Mar. 2014.

[8] N. Daouas, "A study on optimum insulation thickness in walls and energy savings in Tunisian buildings based on analytical calculation of cooling and heating transmission loads," Appl. Energy, vol. 88, no. 1, pp. 156-164, Jan. 2011.

[9] A. D. La Rosa, A. Recca, A. Gagliano, J. Summerscales, A. Latteri, G. Cozzo, and G. Cicala, "Environmental impacts and thermal insulation performance of innovative composite solutions for building applications," Constr. Build. Mater., vol. 55, pp. 406-414, Mar. 2014.

[10] O. Kaynakli, "A review of the economical and optimum thermal insulation thickness for building applications," Renew. Sustain. Energy Rev., vol. 16, no. 1, pp. 415-425, Jan. 2012.

[11] H. Monteiro and F. Freire, "Life-cycle assessment of a house with alternative exterior walls: Comparison of three impact assessment methods," Energy Build., vol. 47, pp. 572-583, Apr. 2012.

[12] A. Ucar and F. Balo, "Determination of the energy savings and the optimum insulation thickness in the four different insulated exterior walls," Renew. Energy, vol. 35, no. 1, pp. 88-94, 2010.

[13] S. Pretot, F. Collet, and C. Garnier, "Life cycle assessment of a hemp concrete wall: Impact of thickness and coating," Build. Environ., vol. 72, pp. 223-231, Feb. 2014.

[14] S. Proietti, U. Desideri, P. Sdringola, and F. Zepparelli, "Carbon footprint of a reflective foil and comparison with other solutions for 
thermal insulation in building envelope," Appl. Energy, vol. 112, pp. 843-855, Dec. 2013

[15] R. Azari, "Integrated energy and environmental life cycle assessment of office building envelopes," Energy Build., vol. 82, pp. 156-162, Oct. 2014.

[16] J. Basbagill, F. Flager, M. Lepech, and M. Fischer, "Application of life-cycle assessment to early stage building design for reduced embodied environmental impacts," Build. Environ., vol. 60, pp. 81-92, Feb. 2013.

[17] S. M. Batouli, Y. Zhu, M. Nar, and N. A. D'Souza, "Environmental performance of kenaf-fiber reinforced polyurethane: A life cycle assessment approach," J. Clean. Prod., vol. 66, pp. 164-173, Mar. 2014.

[18] R. M. Cuéllar-Franca and A. Azapagic, "Environmental impacts of the UK residential sector: Life cycle assessment of houses," Build. Environ., vol. 54, pp. 86-99, Aug. 2012.

[19] T. Gao, L. I. C. Sandberg, and B. P. Jelle, "Nano insulation materials: Synthesis and life cycle assessment," Procedia CIRP, vol. 15, pp. 490-495, 2014.

[20] A. M. Papadopoulos and E. Ã. Giama, "Environmental performance evaluation of thermal insulation materials and its impact on the building," vol. 42, pp. 2178-2187, 2007.

[21] B. L. Peuportier, "Life cycle assessment applied to the comparative evaluation of single family houses in the French context," Energy Build., vol. 33, no. 5, pp. 443-450, May 2001.

[22] C. Rodrigues and F. Freire, "Integrated life-cycle assessment and thermal dynamic simulation of alternative scenarios for the roof retrofit of a house," Build. Environ., vol. 81, pp. 204-215, Nov. 2014.

[23] J. Rives, I. Fernandez-Rodriguez, J. Rieradevall, and X. Gabarrell, "Environmental analysis of raw cork extraction in cork oak forests in southern Europe (Catalonia-Spain)," J. Environ. Manage., vol. 110, pp. 236-45, Nov. 2012.

[24] B. Rossi, A.-F. Marique, and S. Reiter, "Life-cycle assessment of residential buildings in three different European locations, case study," Build. Environ., vol. 51, pp. 402-407, May 2012.

[25] C. Thormark, "A low energy building in a life cycle - its embodied energy, energy need for operation and recycling potential," Build. Environ., vol. 37, no. 4, pp. 429-435, Apr. 2002.
[26] K. Adalberth, "Energy use during the life cycle of single-unit dwellings: Examples," Build. Environ., vol. 32, no. 4, pp. 321-329, Jul. 1997.

[27] A. Forsberg and F. von Malmborg, "Tools for environmental assessment of the built environment," Build. Environ., vol. 39, no. 2 , pp. 223-228, Feb. 2004.

[28] A. Sharma, A. Saxena, M. Sethi, and V. Shree, "Life cycle assessment of buildings: A review," Renew. Sustain. Energy Rev., vol. 15, no. 1 , pp. 871-875, Jan. 2011

[29] G. A. Blengini and T. D. Carlo, "The changing role of life cycle phases, subsystems and materials in the LCA of low energy buildings," Energy Build., vol. 42, no. 6, pp. 869-880, Jun. 2010.

[30] C. K. Chau, F. W. H. Yik, W. K. Hui, H. C. Liu, and H. K. Yu, "Environmental impacts of building materials and building services components for commercial buildings in Hong Kong," J. Clean. Prod. vol. 15 , no. 18 , pp. $1840-1851$, Dec. 2007.

[31] A. Ucar and F. Balo, "Effect of fuel type on the optimum thickness of selected insulation materials for the four different climatic regions of Turkey," Appl. Energy, vol. 86, no. 5, pp. 730-736, May 2009.

[32] Regulamento de Desempenho Energético dos Edifícios de Habitação (REH), Code of the Buildings Thermal Behaviour Characteristics, DL118/August 20, 2013, Portugal, 2013.

[33] International Energy Agency, Modernising Building Energy Codes, 2013.

[34] P. Ricciardi, E. Belloni, and F. Cotana, "Innovative panels with recycled materials: Thermal and acoustic performance and life cycle assessment," Appl. Energy, vol. 134, pp. 150-162, Dec. 2014.

[35] F. Ardente, M. Beccali, M. Cellura, and M. Mistretta, "Building energy performance: A LCA case study of kenaf-fibres insulation board," Energy Build., vol. 40, no. 1, pp. 1-10, Jan. 2008.

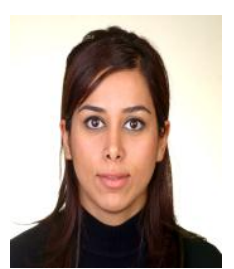

Seyedeh Shiva Saadatian was born in Tehran, Iran in 1985. She earned her bachelor degree in industrial engineering from AZAD University of Tehran in 2009 She gained her master degree in energy for sustainability from University of Coimbra in 2014. She is a $\mathrm{PhD}$ candidate in sustainable energy systems at University of Coimbra under the MIT Portugal Program. 